\title{
Implementasi Kebijakan Retribusi Pelayanan Pasar di Pasar Adiwerna Kabupaten Tegal
}

\section{Implementation of Market Service Retribution Policy In The Adiwerna Market of Tegal Regency}

\author{
Septi Anjani Putri Dwika*, Kismartini \& Ida Hayu Dwimawanti \\ Magister Ilmu Administrasi, Fakultas Ilmu Sosial dan Politik, Universitas Diponegoro, \\ Indonesia
}

Diterima: 21 Januari 2020; Disetujui: 09 Maret 2020; Dipublish: 23 Maret 2020

*Coresponding Email: Putridwika24@gmail.com

\begin{abstract}
Abstrak
Penelitian ini bertujuan mendeskripsikan dan menganalisis bagaimana implementasi kebijakan retribusi pelayanan pasar di Pasar Adiwerna Kabupaten Tegal dan untuk mendeskripsikan dan menganalisis faktor pendukung dan penghambat implementasi kebijakan retribusi pelayanan pasar di Pasar Adiwerna Kabupaten Tegal. Mengenai retribusi pelayanan pasar di Pasar Adiwerna Kabupaten Tegal, masalah di fokuskan kepada Kurangnya staf di Dinas Perdagangan, Koperasi, dan UKM Kabupaten Tegal yang menangani pengelolaan pasar, kurangnya kesadaran wajib retribusi (pedagang) untuk membayar retribusi tepat waktu, kurang tegasnya pihak pelaksana kebijakan/ pengelola pasar dalam menerapkan sanksi bagi para pedagang yang tidak membayar retribusi tepat pada waktunya, banyaknya pedagang pasar yang membuka lapaknya disembarang tempat. Guna mendekati masalah ini dipergunakan acuan teori Van Meter Van Horn. Data- data dikumpulkan melalui wawancara dengan beberapa koresponden dan pengabilan beberapa data pendukung dan dianalisis secara kualitatif. Kajian ini menyimpulkan bahwa ternyata masih ada banyak hal yang perlu untuk diperbaiki apabila dilihat dari keefektivan proses implementasi kebijakan retribusi pelayanan pasar dan faktor-faktor yang mempengaruhinya. Implementasi Kebijakan Retribusi Pelayanan Pasar di Pasar Adiwerna Kabupaten Tegal apabila dilihat dari proses pelaksanaannya dapat dikatakan cukup baik.

Kata Kunci: Implementasi, Retribusi Pasar, Wajib Retribusi
\end{abstract}

Abstract
This study aims to describe and analyze how the implementation of market service levies policy in the Adiwerna Market in Tegal Regency and to describe and analyze the supporting and inhibiting factors for the implementation of market service levies policy in the Tegal Adiwerna Market. Regarding market service levies in the Tegal Regency Adiwerna Market, the problem is focused on the lack of staff at the Tegal Regency Trade, Cooperative and SME Office who handle market management, the lack of awareness of mandatory levies (merchants) to pay levies on time, the lack of policy implementers / market managers in applying sanctions for traders who do not pay fees on time, many market traders are opening shanties everywhere. To approach this problem a reference to the Van Meter Van Horn theory is used. Data were collected through interviews with several correspondents and withholding some supporting data and analyzed qualitatively. This study concludes that there are still many things that need to be improved when viewed from the effectiveness of the implementation process of market service levies and the factors that influence it. The implementation of the Market Service Levies Policy in the Adiwerna Market of Tegal Regency when viewed from the implementation process can be quite good.

Keywords: Implementation, Market Levy, Mandatory Retribution

How to Cite: (2020). Implementasi Kebijakan Retribusi Pelayanan Pasar di Pasar Adiwerna Kabupaten Tegal. Journal of Education, Humaniora and Social Sciences (JEHSS). 2 (3): 561-572. 


\section{PENDAHULUAN}

Pasar tradisional merupakan tempat bertemunya penjual dengan pembeli yang ditandai dengan adanya transaksi penjual dan pembeli secara langsung. Dalam pasar tradisional terjadi yang namanya proses tawar- menawar, bangunan terdiri dari kioskios, loos dan dasaran terbuka yang dibuka oleh penjual maupun pengelola pasar (Erdaini, 2015).

Berdasarkan Undang-undang Nomor 28 Tahun 2009 Tentang Pajak Daerah dan Retribusi Daerah, yang selanjutnya disebut Pajak Daerah adalah pajak yang dipungut oleh pemerintah daerah dan juga merupakan salah satu sumber penerimaan penting yang akan digunakan untuk membiayai penyelenggaraan pemerintah daerah dan pembangunan daerah (Najoan, Sabijono, \& Datu, 2016).

Retribusi Daerah adalah pungutan daerah sebagai pembayaran atas jasa atau pemberian izin tertentu yang khusus disediakan dan atau diberikan oleh Pemerintah Daerah untuk kepentingan orang pribadi atau badan (Chotimah, 2015).

Adapun jenis retribusi daerah yang dapat dipungut oleh Pemerintah Daerah adalah sebagai berikut :

Tabel 1.1 Penggolongan Retribusi Daerah

\begin{tabular}{|c|c|c|}
\hline Jasa Umum & Jasa Usaha & Perizinan Tertentu \\
\hline Retribusi Pelayanan Pasar & Retribusi Pasar Grosir & $\begin{array}{lll}\text { Retribusi } & \text { Izin } & \text { Mendirikan } \\
\text { Bangunan } & & \end{array}$ \\
\hline $\begin{array}{l}\text { Retribusi Pelayanan Parkir di } \\
\text { Tepi Jalan Umum }\end{array}$ & Retribusi Terminal & 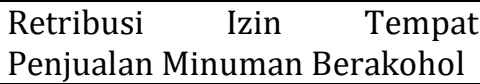 \\
\hline Retribusi Pelayanan Kesehatan & Retribusi Tempat Penginapan & Retribusi Izin gangguan \\
\hline $\begin{array}{ll}\text { Retribusi } & \text { Pelayanan } \\
\text { Persampahan } & \\
\end{array}$ & Retribusi Rumah Potong Hewan & Retribusi Izin Trayek \\
\hline $\begin{array}{l}\text { Retribusi Pengujian Kendaraan } \\
\text { Bermotor }\end{array}$ & $\begin{array}{l}\text { Retribusi Tempat rekreasi dan } \\
\text { Olahraga }\end{array}$ & Retribusi Izin Usaha Perikanan \\
\hline
\end{tabular}

Sumber : (Defitri, 2015)

Berdasarkan tabel tersebut di atas, retribusi pelayanan pasar termasuk dalam retribusi jasa umum. Dalam peraturan mengenai retribusi pasar di Kabupaten Tegal sendiri diatur pada Peraturan Daerah Nomor 2 Tahun 2012 Tentang Retribusi Pelayanan Pasar yang berisi tentang besarnya tarif retribusi, prosedur pembayaran, obyek retribusi pasar dan hal-hal lainnya. Kabupaten Tegal adalah salah satu kabupaten yang terletak di bagian barat laut Provinsi Jawa Tengah, Indonesia yang memiliki luas 876,10 $\mathrm{km}^{2}$. Pusat administrasinya dulu berada di Kota Tegal yang terletak di sudut barat laut kabupaten ini, akan tetapi kemudian Kota Tegal secara administratif terpisah dari kabupaten dan membentuk wilayah sendiri, kemudian 
Vol 2, No. 3, April 2020: 561-572, DOI: 10.34007/jehss.v2i3.112

digantikan oleh Kota Adiwerna sebagai pusat adminitrasi Kabupaten Tegal hingga saat ini, yang merupakan pinggiran kota yang terletak sekitar $20 \mathrm{~km}$ dari selatan pusat kota dan dalam batas kabupaten.

Kabupaten Tegal mempuyai 18 Kecamatan, dan hampir di setiap Kecamatan memiliki pasar sebagai representasi hubungan sosial-ekonomi di Kabupaten Tegal. Rata-rata pasar di masing-masing kecamatan adalah pasar tradisional, jumlah keseluruhan 26 pasar tradisional, dimana salah satunya ialah Pasar Adiwerna yang merupakan salah satu pasar tradisonal terbesar di Kabupaten Tegal yang terletak di Kecamatan Adiwerna. Tepatnya berada di Desa Adiwerna, Kabupaten Tegal. Pasar Adiwerna merupakan salah satu pasar golongan kelas I di Kabupaten Tegal, dimana beberapa pasar golongan kelas I lainnya adalah Pasar Trayeman, Pasar Banjaran, dan Pasar Margasari. Menjadi salah satu pasar tradisional di tengah Kota, menjadikan pasar tersebut ramai oleh pedagang yang ingin berjualan. Pembagian waktu berjualanpun sudah diatur oleh pengelola pasar agar pedagang dapat tertib dan teratur membuka lapak.

Setelah jam berjualan dari pagi hingga siang selesai, kegiatan jual beli di Pasar Adiwerna dilakukan kembali dari sore hingga malam hari. Meskipun pengaturan jam berjualan sudah diatur oleh pengelola Pasar Adiwerna, namun salah satu pegawai dari Dinas Koperasi, UMKM dan Perdagangan yaitu Bapak Bintang selaku bagian perizinan, mengatakan bahwa kemungkinan masih ada pedagang yang membuka lapaknya tanpa ijin karena jumlah pedagang yang sangat banyak dan kegiatan jual beli dilakukan pada malam hari sehingga menyulitkan petugas dalam melakukan pendataan wajib retribusi.

Permasalahan lain yang terjadi dalam pengelolaan retribusi pasar di Pasar Adiwerna ialah tidak selalu tercapainya target pendapatan retribusi pasar yang telah ditetapkan sebelumnya.

Berikut data target dan realisasi pendapatan retribusi pelayanan pasar di Pasar Adiwerna Kabupaten Tegal dari tahun 2015 sampai dengan tahun 2018 :

Tabel 1.2 Target dan Realisasi Pendapatan Retribusi Pelayanan Pasar (Pasar Adiwerna Tahun 2015-2018)

\begin{tabular}{cccc}
\hline Tahun & Target & Realisasi & \% \\
\hline $\mathbf{2 0 1 5}$ & 195.000 .000 & 195.010 .000 & $100.09 \%$ \\
\hline $\mathbf{2 0 1 6}$ & 211.694 .000 & 163.530 .000 & $77.24 \%$ \\
\hline $\mathbf{2 0 1 7}$ & 225.105 .000 & 220.300 .000 & $97.86 \%$ \\
\hline $\mathbf{2 0 1 8}$ & 243.770 .000 & 198.720 .000 & $81.51 \%$ \\
\hline
\end{tabular}

Sumber : Dinas Koperasi, UMKM, dan Perdagangan Kabupaten Tegal, 2018 
Berkaitan dengan Peraturan Daerah Kabupaten Tegal Nomor 2 Tahun 2012 tentang Retribusi Jasa Umum khususnya pengelolaan retribusi pelayanan pasar, pemerintah daerah berupaya meminimalisir masalah yang muncul dengan memberlakukan atau melaksanakan sistem pungutan sesuai dengan petunjuk yang ada dalam Perda, sebagai contoh dengan menentukan besarnya tarif retribusi pelayanan pasar berdasarkan Perda Paragraf 4 Pasal 35 tentang struktur dan besarnya tarif.

Besarnya tarif retribusi pelayanan pasar ditetapkan menjadi beberapa kategori sesuai dengan kelas yang sudah digolongkan dengan kriteria tertentu (Hendrawan, Kusmanto \& Warjio, 2018). Selain itu juga terdapat pedoman tata cara penagihan dengan mempertimbangkan kemampuan masyarakat dan aspek keadilan (Mubarok, 2016).

Permasalahan mengenai implementasi kebijakan retribusi pelayanan pasar di Pasar Adiwerna Kabupaten Tegal, diantaranya banyak pedagang yang berjualan di pelataran Pasar Adiwerna pada sore dan malam hari menyebabkan petugas kurang maksimal dalam melakukan pendataan wajib retribusi, Banyaknya pedagang yang membayar retibusi tidak sesuai dengan ketentuan tarif yang ditetapkan dimana pernyataan tersebut disampaikan oleh kepala UPTD Pasar Adiwerna yaitu Bapak Sudirman.

Permasalahan selanjutnya belum tercapainya target penerimaan retribusi pasar yang sudah ditentukan oleh DPPKAD pada tahun 2015-2018. Permasalahanpermasalahan tersebut tentunya menjadi tugas bagi Dinas Koperasi, UMKM, dan Perdagangan serta Kantor Pelayanan Pasar Adiwerna sebagai pihak yang mengelola kebijakan pelayanan pasar.

Untuk melihat bagaimana Implementasi Kebijakan Retribusi Pelayanan Pasar di Pasar Adiwerna, penulis mengacu dari teori pakar dalam melaksanakan tahapan proses kebijakan, antara lain: SOP, Implementor Kebijakan \& Tugas Pokok dan Fungsinya, Sasaran Kebijakan. Sedangkan untuk mengetahui apa saja faktor pendukung dan penghambat dalam pelaksanaan Implementasi Kebijakan Retribusi Pelayanan Pasar di Pasar Adiwerna, penulis mengambil teori yang dikemukakan oleh Van Meter dan Van Horn antara lain: Sumber Daya, Komuniksi dan Kegiatan Pelaksana, Karakteristik Agen Pelaksana, Kondisi Ekonomi Sosial Politik, Disposisi Imlementor (Narsih, 2015). 


\section{METODE PENELITAN}

Metode penelitian yang digunakan adalah metode kualitatif. Metode kualitatif menurut Bogdan dan Taylor merupakan prosedur penelitian yang menghasilkan data deskriptif berupa kata-kata tertulis atau lisan dari orang-orang dan perilaku yang dapat diamati (Prastowo, 2011). Penelitian ini terfokus pada Implementasi Kebijakan Retribusi Pelayanan Pasar dan kendala-kendala yang terdapat didalam pelaksanaannya dengan menggunakan metode kualitatif karena berupaya untuk menyajikan data dan informasi secara mendalam sehingga menghasilkan gambaran mengenai Implementasi Kebijakan Retribusi Pelayanan Pasar di Pasar Adiwerna Kabupaten Tegal.

\section{HASIL DAN PEMBAHASAN}

\section{Implementasi Kebijakan Retribusi Pasar di Pasar Adiwerna Kabupaten Tegal.}

Implementasi kebijakan merupakan suatu proses yang dinamis, dimana pelaksana kebijakan melaksanakan serangkaian aktivitas atau kegiatan sehingga pada akhirnya akan mendapatkan hasil yang sesuai dengan tujuan yang telah ditetapkan dari kebijakan tersebut. Keberhasilan suatu implementasi kebijakan tentunya tidak terlepas dari proses-proses atau tahapan-tahapan dari kebijakan itu sendiri (Gabriel , 2015).

Dalam penelitian tentang implementasi kebijakan retribusi pelayanan pasar di Pasar Adiwerna Kabupaten Tegal untuk proses pelaksanaannya dapat dilihat dari aspek standar operasional prosedur (SOP), implementor kebijakan dan tupoksinya serta sasaran kebijakan dan Kinerja atau hasil Implementasi.

\section{Standar Operasional Prosedur (SOP)}

Struktur organisasi-organisasi yang melaksanakan kebijakan memiliki pengaruh penting pada implementasi. Salah satu dari aspek-aspek struktural paling dasar dari suatu organisasi adalah prosedur-prosedur kerja ukuran dasarnya (Standart Operating Procedure, SOP) (Zuraida, 2012).

Prosedur-prosedur digunakan untuk menanggulangi keadaan-keadaan umum yang ada dalam organisasi publik dan swasta. Dengan menggunakan SOP, para pelaksana dapat memanfaatkan waktu yang tersedia. Selain itu SOP juga menyeragamkan tindakan-tindakan dari para pejabat dalam organisasi-organisasi yang kompleks dan tersebar luas (Winarno, 2012).

Berdasarkan pernyataan para informan, dapat disimpulkan bahwa pelaksanaan kebijakan retribusi pelayanan pasar sudah dijalankan sesuai dengan ketentuan Standar 
Operasional Prosedur yang ada. Ditandai dengan pembagian tugas masing-masing pihak pelaksana kebijakan yang sudah dilaksanakan dengan baik dan jelas. Meskipun untuk hasil pendapatan retribusi pasar tidak selalu mencapai target yang telah ditetapkan.

Dapat dijadikan acuan bagi pelaksana kebijakan (Dinas Perdagangan, Koperasi, dan UKM Kab. Tegal dan Kantor UPTD Pasar Adiwerna) dalam bertindak dan melaksanakan kebijakan retribusi pelayanan pasar sesuai dengan peraturan yang berlaku

Dapat dijadikan dasar pelaksanaan bagi Dinas Perdagangan, Koperasi, dan UKM Kab. Tegal sebagai implementor dalam memberikan sosialisasi, pengarahan serta tata cara pemberian informasi kepada wajib retribusi mengenai peraturan kebijakan yang ada. SOP sudah dijalankan dengan baik oleh Dinas Perdagangan, Koperasi, dan UKM Kab. Tegal dan Kantor UPTD Pasar Adiwerna serta wajib retribusi/ pedagang

\section{Implementor Kebijakan dan Tupoksi}

Kesuksesan suatu implementasi kebijakan sangat dipengaruhi oleh para implementor kebijakan yang terlibat didalamnya menjelaskan tentang unsur-unsur dari implementasi kebijakan yang mutlak harus ada yaitu : 1) Unsur Pelaksana; 2) Adanya Program Yang dilaksanakan; 3) Target Group atau Kelompok Sasaran (Tachjan, 2006).

Kebijakan retribusi pelayanan pasar merupakan kebijakan yang melibatkan berbagai pihak dalam pelaksanaannya, diantaranya:

a. Dinas Perdagangan, Koperasi, dan UKM Kab. Tegal dan Kantor UPTD Pasar Adiwerna merupakan aktor pelaksana dari kebijakan retribusi pelayanan pasar. Hal ini tertuang dalam Peraturan Bupati Tegal Nomor 2 Tahun 2012.

b. Aktor kebijakan retribusi pelayanan pasar yang lain sifatnya hanya membantu proses pelaksanaan antara lain, DPPKAD sebagai instansi yang menerima setoran retribusi pasar karena sebagai instansi yang mengurus kas daerah, DPU membantu mengurus permasalahan pengelolaan kebersihan Pasar Adiwerna dan Satpol PP membantu menertibkan para pedagang kaki lima yang berjualan didepan pasar tanpa ijin.

c. Implementasi kebijakan retribusi pelayanan pasar dilaksanakan oleh Dinas Perdagangan, Koperasi, dan UKM Kab. Tegal bidang pengelolaan pasar dengan terbagi menjadi 3 (tiga) seksi yang pertama yakni Seksi Retribusi dan Perijinan 
dengan mempunyai tugas pokok dan fungsi : Penelaah data sebagai bahan penyusun rencana kerja (1), Penelaah data sebagai bahan perumusan kebijakan umum dan teknis pengelolaan perijinan pedagang pasar (2), Pelaksanan bimbingan dan pengendalian tekis pengelolaan perizinan pedagang pasar (3), Pelaksanaan teknis operasional dan administratif pegelolaaan perizinan pedagang pasar (4), Pengkajian potensi dan target pendapatan pasar (5), Pengendalian, evaluasi dan pelaporan pelaksanaan tugas Seksi Perizinan Pedagang Pasar (6). Seksi yang kedua yakni Sub Bagian Umum dan Kepegwaian dengan tugas pokok dan fungsi : (1) Penelaah data sebagai bahan penyusunan rencana kerja; (2)Penelaah data sebagai bahan perumusan kebijakan tekis pengelolaan urusan umum dan kepegawaian; (3) Pengelolaan urusan ketatausahaan; (4) Pengelolaan administrasi kepegawaian, (5) Pengelolaan aset Dinas, (6) Pengeolaan kearsipan Dinas , (7)Pelaksanaan urusan rumah tangga, perlengkapan, perpustakaan, humas, dan protokol; (8)Pengendalian, evaluasi dan pelaporan pelaksanaan tugas Subbagian Umum dan Kepegawaian.

Dalam pelaksanaan implementasi kebijakan retribusi pelayanan pasar di Pasar Adiwerna Kabupaten Tegal ketiga seksi tersebut mengalami berbagai kendala pada masing-masing tupoksi.

Berdasarkan hasil wawancara dengan beberapa informan, dapat ditarik kesimpulan pada Tahun 2016-2018 pendapatan retribusi pasar di Pasar Adiwerna tidak mencapai target yang telah ditetapkan dikarenakan beberapa permasalahan, salah satunya banjir yang pernah menerjang Pasar Adiwerna membuat aktivitas di Pasar Adiwerna menjadi terganggu karena tingginya volume air yang masuk di Pasar Adiwerna.

\section{Sasaran Kebijakan}

Pedagang merupakan sasaran atau target dari kebijakan retribusi pelayanan pasar. Pedagang membayar retribusi ke juru pungut sesuai dengan tarif retribusi yang sudah ditentukan di dalam Peraturan Daerah dan juga Peraturan Bupati dan dalam waktu yang sudah ditentukan sebelumnya, besar kecilnya tarif retribusi didasarkan pada luas lapak dan fasilitas yang tersedia. Semakin luas daerah dagangan semakin besar juga retribusi yang harus dibayarkan, serta semakin lengkap fasilitas yang disediakan juga semakin besar retribusi yang harus dibayarkan (Tidore, 2015).

Sasaran kebijakan pada implementasi kebijakan retribusi pelayanan pasar di Pasar Adiwerna Kabupaten Tegal sudah sesuai dengan Peraturan Daerah Nomor 2 
Tahun 2012 bagian kelima tentang Pedoman Pelaksanaan Retribusi Pelayanan Pasar (Retribusi Jasa Umum) yang tertuang pada Pasal 30 dan 31.

Berdasarkan hasil wawancara dengan beberapa informan, dapat disimpulkan, sasaran kebijakan adalah para pedagang yang berjualan dilingkungan Pasar Adiwerna, dan berdasarkan pendapat para informan tersebut fasilitas pemerintah yang diberikan kepada para sasaran kebijakan dalam hal ini pedagang, hanya berupa luasan tempat berjualan baik berupa los, kios, lapak serta fasilitas penunjang lainnya berupa speaker dan mikrofone yang berguna untuk manyampaikan informasi dan selebaran jika ada pengumuman seperti kenaikan tarif retribusi. Selain itu bentuk jasa lainnya ialah jasa kebersihan dengan membayar retribusi kebersihan setiap harinya. Fasilitas lain seperti toilet, merupakan fasilitas yang dikelola oleh pihak ketiga.

\section{Faktor Pendukung dan Penghambat Implementasi Kebijakan Retribusi} Pelayanan Pasar di Pasar Adiwerna Kabupaten Tegal.

\section{Faktor Pendukung}

\section{a. Sumber Daya Manusia}

Sumber Daya Manusia utama dalam implementasi kebijakan retribusi pelayanan pasar ini adalah staf/ pegawai Dinas Perdagangan, Koperasi, dan UKM Kabupaten Tegal. Dinas Perdagangan, Koperasi, dan UKM Kabupaten Tegal merupakan pelaksana kebijakan di Pasar Adiwerna. Dimana Dinas tersebut harus disiplin dalam pelaksanaannya dan harus kompeten sesuai bidangnya. Pemungutan retribusi Pasar Adiwerna ini harus merata. Mengingat Pasar Adiwerna ini mempunyai wilayah yang cukup luas, serta jumlah pedagang Pasar Adiwerna terhitung banyak.

Berdasarkan hasil wawancara dengan beberapa informan, untuk kualitas di Dinas Perdagangan, Koperasi, dan UKM Kabupaten Tegal maupun Kantor UPTD Pasar Adiwerna dirasa sudah cukup baik karena latar belakang pendidikan para pegawai/staf minimal S1/D3. Akan tetapi untuk kuantitas atau jumlah pegawai, para informan menyampaikan kekurangan staf, sedangkan jumlah pekerjaan yang di jalankan tidak sedikit.

\section{b. Komunikasi dan Kegiatan Pelaksana}

Implementasi kebijakan retribusi pelayanan pasar akan berjalan efektif apabila sasaran kebijakan mengerti akan apa yang menjadi tujuan utama dari kebijakan tersebut. Agar tujuan utama tersebut dapat dipahami dan dimengerti dengan baik, 
maka dibutuhkan suatu komunikasi yang baik pula. Komunikasi yang baik terwujud apabila informasi yang diberikan tepat, seragam dan juga konsisten (Murtiani, Subroto, \& Kurniadi, 2016).

Berdasarkan hasil wawancara, menunjukkan bahwa komunikasi dan kegiatan pelaksana dalam implementasi kebijakan retribusi pelayanan pasar di Pasar Adiwerna Kabupaten Tegal sudah baik, informasi yang diberikan kepada sasaran kebijakan yaitu pedagang sudah dirasa dimengerti dan dipahami oleh para pedagang.

\section{c. Karakteristik Agen Pelaksana}

Karakteristik agen pelaksana menunjuk seberapa besar daya dukung struktur organisasi, nilai-nilai yang berkembang, hubungan dan komunikasi yang terjadi diinternal birokrasi (Mubarok, 2016).

Berdasarkan hasil wawancara, maka koordinasi Dinas Perdagangan, Koperasi, dan UKM Kabupaten Tegal dengan berbagai pihak yang terkait selama ini sudah berjalan dengan baik. Koordinasi tersebut dilakukan dengan instansi seperti DPU, DPPKAD, Satpol PP, dan bentuk koordinasi tersebut dilaksanakan dalam bentuk rapat rutin seminim-minimnya saru bulan sekali untuk membahas perasalahan serta evaluasi retibusi.

\section{d. Kondisi Sosial Ekonomi Politik}

Suatu kebijakan apabila diterapkan tidak akan lepas dari aspek ekonomi sosial maupun politik yang mempengaruhinya, konsekuensi dampak ekonomi maupun sosial atas dilaksanakannya kebijakan pun terkadang tidak dapat dihindarkan. Seperti halnya kebijakan retribusi pelayanan pasar, yang dalam pelaksanaannya sangat dipegaruhi oleh keadaan ekonomi politik serta sosial baik positif maupun negative (Sebastian, 2015).

Berdasarkan pendapat masing-masing informan mengenai dampak ekonomi dan sosial dari kebijakan retribusi pasar dapat dilihat dari berbagai macam sudut pandang. Antara lain dampak ekonomi untuk Kabupaten Tegal adanya kebijakan retribusi pelayanan pasar ini dapat menambah pemasukan PAD bagi Kabupaten Tegal. Sedangkan dilihat dari aspek sosial, adanya kebijakan retribusi pelayanan pasar ini merupakan media penyaluran pemenuhan kebutuhan masyarakat terhadap penyediaan bahan kebutuhan sehari-hari dengan pelayanan jasa penyediaan pasar tradisional. 


\section{e. Disposisi Implementor}

Disposisi implementor mencakup tiga hal penting, yakni (a) Respons implementor terhadap kebijakan, yang akan mempengaruhi kemauannya untuk melaksanakan kebijakan; (b) Kognisi, yakni pemahamannya terhadap kebijakan dan (c) Intensitas disposisi implementor, yakni preferensi nilai yang dimiliki oleh implementor (Subarsono, 2010).

Berdasarkan pendapat informan, kebijakan retribusi pelayanan pasar ini penting adanya karena sebagai acuan pelaksanaan tugas mereka. Sedangkan untuk pedagang kebijakan ini juga dirasa sangat penting karena digunakan sebagai pedoman para wajib retribusi apabila ingin berjualan dilingkungan Pasar Adiwerna.

\section{Faktor penghambat}

a. Kurangnya staf di Dinas Perdagangan, Koperasi, dan UKM Kabupaten Tegal yang menangani pengelolaan pasar.

b. Kurangnya kesadaran wajib retribusi (pedagang) untuk membayar retribusi tepat waktu.

c. Banyaknya pedagang pasar yang membuka lapaknya disembarang tempat (dijalan tempat pengunjung pasar berlalu lalang) dan dihalaman pasar sehingga mengurangi nilai estetika pasar serta menyebabkan pasar terlihat semrawut dan tidak tertata rapi.

d. Kurang tegasnya pihak pelaksana kebijakan/ pengelola pasar dalam menerapkan sanksi bagi para pedagang yang tidak membayar retribusi tepat pada waktunya.

e. Perpindahan hak milik dari pedagang lama ke pedagang baru tanpa pemberitahuan kepada Kantor UPTD Pasar.

f. Pelaksanaan penarikan retribusi pasar belum diimbangi dengan perbaikan pelayanan yang diberikan karena masih terdapat beberapa kerusakan fasilitas didalam pasar.

g. Luas lahan pasar yang tidak diimbangi dengan banyaknya jumlah pedagang, menyebabkan banyak pedagang yang membuka lapak tanpa ijin.

h. Kualitas kebersihan, kerapihan dan keindahan pasar belum terjamin secara optimal dimana hal tersebut menyebabkan keengganan pedagang untuk membayar retribusi tepat waktu. 
i. Masih sering terjadinya banjir pada saat musim penghujan tiba, membuat aktivitas penjualan dipasar Adiwerna terganggu bahkan terjadinya banjir tahunan membuat beberapa fasilitas pasar menjadi rusak.

\section{SIMPULAN}

Implementasi Kebijakan Retribusi Pelayanan Pasar di Pasar Adiwerna Kabupaten Tegal, ternyata masih ada banyak hal yang perlu untuk diperbaiki apabila dilihat dari keefektivan proses implementasi kebijakan retribusi pelayanan pasar dan faktor-faktor yang mempengaruhinya. Diperlukan Penambahan jumlah staf pada bidang pengelolaan pasar di Dinas Perdagangan, Koperasi, dan UKM Kabupaten Tegal. Pelaksana kebijakan seharusnya lebih tegas untuk menerapkan sanksi administrasi kepada para pedagang yang tidak tepat waktu dalam membayarkan retribusinya agar para pedagang lebih disiplin dalam membayar retribusi. Pengelola Pasar Adiwerna harus lebih tegas lagi. Peningkatan sosialisasi tentang retribusi pelayanan pasar dan juga peraturan-peraturan yang harus dipatuhi kepada para pedagang Pasar Adiwerna. Melakukan pendataan dan monitoring wajib retribusi secara rutin, untuk mengurangi permasalahan perpindahan hak milik dari pedagang lama ke pedagang baru secara ilegal.

\section{UCAPAN TERIMAKASIH}

Terimakasih kepada Ketua prodi Magister Ilmu Administrasi Publik beserta staf akademik lainnya, juga turut serta saya sampaikan terimakasih kepada dosen pembimbing dan Keluarga beserta teman-teman yang telah memberikan dukungan secara moral kepada saya.

\section{DAFTAR PUSTAKA}

Chotimah, E. T. (2015, September 20). Analisis Penerimaan Retribusi Pasar Terhadap Kinerja Kualitas Pelayanan Pasar Tradisional Kota Semarang (Studi Kasus Pasar Johar). Jurnal Online Supports Scientific Communities, 3(1), 60-66.

Defitri, S. Y. (2015, September 20). Pengaruh Retribusi Pelayanan Pasar Terhadap Retribusi Daerah Sebagai Sumber PAD Solok. Jurnal Online Support Scientific Communities, 4(2), 56-61.

Erdaini, Y. N. (2015). Mekanisme Pemungutan, Penyetoran Dan Pelaporan Retribusi Harian Pasar Umum Pada Unit Pasar Tegal Besar Dinas Pasar Kabupaten Jember.

Gabriel , G. J. (2015, September 30). The Subsumption Of Traditional Fishing To Market Demands In Rosario Argentina. International Journal Of Academic Research, 4(2), 77-82.

Hendrawan, A.I. Kusmanto, H. \& Warjio. (2018). Pengaruh Kualitas Pelayanan terhadap Kepuasan Publik di Badan Pengelolaan Pajak dan Retribusi Daerah Kota Medan. Jurnal Administrasi Publik: Public Administration Journal. 8 (1): 65-84. 
Mubarok, D. H. (2016). Potensi Penerimaan Retribusi Pelayanan Pasar Dan Kontribusi Serta Prospeknya Terhadap PAD Kota Samarinda. Jurnal Ekonomi, Menejemen dan Akuntansi, Universitas Mulawarman, Indonesia, 18.

Murtiani, Subroto, \& Kurniadi. (2016). Sistem Informasi Retribusi Pedagang Pasar Kabupaten Semarang. Jurnal Transistor Elektro dan Informatika, 1.

Najoan, Sabijono, \& Datu. (2016). Analisis Sistem Pemungutan dan Penyetoran Retribusi Pasar Pada Dinas Perindustrian Perdagangan Koperasi Dan Penanaman Modal Kota Kotamobagu. Jurnal Emba, 4.

Narsih, F. (2015, September 20). Pengelolaan Penerimaan Retribusi Pasar dan Persepsi Pedagang Pada Kualitas Pelayanan Pasar di Pasar Tradisional Sumpiuh. Jurnal Online Supports Scientific Communities, 11(6), 71-75.

Prastowo, A. (2011). Metode Penelitian Kualitatif. Yogyakarta: Ar-Ruzz Media.

Sebastian, G. (2015, September 30). New And Old Market - Based Instruments For Climate Change Policy. International Journal of Academic Research, 4(2), 41-45.

Subarsono, A. (2010). Analisis Kebijakan Publik. Yogyakarta: Pustaka Belajar.

Tachjan, D. (2006). Implementasi Kebijakan Publik. Bandung: AIPI.

Tidore. (2015, September 20). Penerimaan Retribusi Pasar Dalam Upaya Meningkatkan PAD Kota. Journal Online Supports Scientific Communities, 2(2), 1090-1103.

Winarno, B. (2012). Kebijakan Publik Teori, Proses, dan Studi Kasus (Revisi Terbaru). Jakarta: CAPS.

Zuraida, I. (2012). Teknik Penyusunan Peraturan Daerah. Jakarta: Sinar Grafika. 